\title{
Teaching digital models: secondary technology teachers' experiences
}

\author{
Helen Brink $^{1}$ (D) . Nina Kilbrink ${ }^{1}$ (D) Niklas Gericke ${ }^{1}$ (D)
}

Accepted: 11 February 2021 / Published online: 2 March 2021

(C) The Author(s) 2021

\begin{abstract}
In secondary technology education, models of artifacts, systems and processes, visualized and simulated through digital tools (digital models) are a relatively new element. Technology teachers teach digital models to meet syllabus criteria of digital competence, applicable to for instance problem solving and documentation using digital tools. However, there is a lack of knowledge concerning how teachers use digital models in their teaching, what their intentions are, and what content they choose. It is known, though, that teachers' experiences influence the teaching. Therefore, the aim of this study is to investigate teachers' experiences of teaching digital models in compulsory school, to contribute to more knowledge of teaching in this area. This study takes a phenomenological lifeworld approach, and 12 semi-structured interviews with lower secondary technology teachers form the empirical data. The data were analyzed thematically and the results are four themes of experiencing the teaching of digital models, indicating that technology teachers teach with different aims and purposes; Enhancing and integrating other subjects, Visualizing technology to the pupils, Enabling digital modelling, and Preparing pupils for the future. Further, the results also indicate that the content and methods of teaching differ and that teachers did not experience digital models as one single idea but as an amalgam of multiple ideas. These findings can be used as a basis for further research and development of teaching concerning digital models.
\end{abstract}

Keywords Digital models · Technology education · Phenomenology · Thematic analysis · Experience

\section{Introduction}

Technology education in lower secondary school takes many different forms in different countries and the syllabuses also differ. However, a common aspect of technology education in several counties is the use of models, both as a pedagogical tool and as a teaching content, for instance in New Zealand, Ireland, and Sweden (Ministry of New Zealand 2017; Department of education \& skills, 2017; Skolverket 2011; Nia and De Vries 2016).

Helen Brink

helen.brink@kau.se

$1 \quad$ Karlstad University, Karlstad, Sweden 
Models in technology education are used to visualize technological systems, objects, and artifacts. Models are also used in design processes, when pupils are solving different problems. Today, more and more teachers include digital models (models visualized on a digital screen) in their teaching to meet the syllabus criteria concerning digital competence (Skolverket 2011). In this teaching the use of digital models can be divided into teaching in technology where technology is developed and sometimes teaching about technology where a digital model can be used for assessing or examine technology (Kilbrink 2013; Svensson 2011). The concept teaching digital models should be understood as teaching in and/or about digital models. Teaching digital models also includes pupils designing and modelling using digital tools, i.e. digital modelling. When introducing digital technologies to a content, it will influence both teaching and content. As digital technologies are introduced and evolve in technology education, the teachers' knowledge of these technologies and how to teach them also needs to be developed (Mishra and Koehler 2006). This is a major change in the teaching profession. The former analogue technologies were more stable (Mishra and Koehler 2006). Research shows that it is difficult for teachers to learn not only hardware and software, but also to learn how to use digital technologies in different situations and in an educational manner (Koehler and Mishra 2005). However, very little is known about how technology teachers teach digital models in different situations.

Research in Swedish schools shows that technology teachers are free to design their technology education based on personal and local references, but at the same time, many teachers express that they are uncertain in their professional practice and also uncertain concerning how they should interpret the syllabus (Bjurulf 2008; Hartell 2015). Further, technology education has no national test to support equivalent teaching in Sweden. As a result of that, technology education takes many different forms in different schools, and it can also differ a great deal in the same school (Skolinspektionen 2014). There is also a recent report (Skolinspektionen 2019), showing that the use of digital tools in lower secondary technology education, which is compulsory, differs between schools. Some of the inspected schools use digital tools in the designated areas mentioned in the technology syllabus and some schools inspected have a more developed pedagogy considering the use of digital tools, which might mean for instance that pupils can work with different tools depending on individual needs. Further findings noted by the school inspectorate are that different schools have different conditions for collaborating on planning lessons where digital tools are used. Some schools have well planned conferences while the technology teachers in other schools rarely meet at all. In addition, a great many areas in technology education are unreflected, in the sense that the pupils are doing things without reflecting upon either the content or their learning (Skolinspektionen 2014). It is important to find out if these conditions, mentioned above, affect the teaching of digital models.

Further, learning is always about something (Marton 2015) and teaching is one way (but not the only way) to organize work in the classroom in order to make learning possible. Something is to be learned in some particular way. Teaching consists of content, something meant to be learned, and methods, ways for pupils to achieve the content. It is known that teachers' experiences of the subject matter and teaching content influence teaching (Marton and Tsui 2004; Mishra and Koehler 2006). That can be explained by the fact that different persons experience a phenomenon in the lifeworld (the world where a person acts and interacts with different subjects and objects) in different ways depending on e.g. previous experiences and knowledge (Bengtsson 2013). Finding out more about teachers' experiences of teaching digital models can help establish a common knowledge base and a common language among the teachers, and knowledge in this area needs to be enhanced. With more knowledge of teachers' experiences, content and teaching - that is, the what-aspect 
and how-aspect of teaching digital models - can be discussed. Since digital models, visualized through digital tools, is a relatively new teaching area, is it important to understand more about teachers' experiences of their teaching and how they interpret the syllabus. Results from this study can help develop the technology teacher profession and contribute to discussions of what should constitute the core content of technology education, as well as how teaching this specific area can be done.

\section{Aim and research question}

The aim of this study is to describe lower secondary technology teachers' experiences of teaching digital models using digital tools. Very little is known about this teaching conducted in compulsory schools today. With this aim as the point of departure, the following research question was formulated:

How do lower secondary technology teachers experience the teaching of digital models?

The studied phenomenon is teaching digital models in lower secondary technology education, and the results presented in this article are descriptive themes of teachers' experiences.

\section{Background}

There are studies pointing to teachers' beliefs about and understandings of technological knowledge as important for technology education (de Vries 2005). It is important to help pupils to acquire a conceptual basis, and teachers should ask themselves What do I mean with technological knowledge in this area? (de Vries 2005). Similarly, it is also likely that teachers' beliefs and understandings are important for teaching digital models. To better understand the results of this study, technological knowledge and the character of the technology subject will be clarified.

Mitcham (1994) defines technological knowledge as having both practical and cognitive dimensions and he continues to describe technology as an activity, producing and using technology, activities with hand and mind. De Vries (2005) argues that teaching technological knowledge should also include a normative component, to teach pupils to assess the functions of artifacts (in a school context that can be functions of a model). A model, representing something in technology education, can be seen as a bridge between theory and the lived world, and Nia and DeVries (2016) suggest that models have an epistemic function; technological knowledge can be developed by using and manipulating models. So, technology education has a dual nature (Gibson 2009); it is both practical and theoretical and technological knowledge consists of a mix of both.

Yet another way to describe technological knowledge, characteristic for technology education, is to distinguish between pupils learning in technology and pupils learning about technology (Kilbrink 2013; Svensson 2011). Knowledge in technology concerns handling and developing technology and knowledge about technology concerns assessing and examining technology. A teaching content in technology education can then be both in and about technology. Pupils engage in a technical activity while developing knowledge of a specific content. The practical activities also deepen other aspects of technology for the pupils, such as methods of technology and developments of products and artifacts (Bjurulf 2011). Theoretical material should be used in technology 
education together with more practical activities in order to achieve holistic learning (Gibson 2009) and research elsewhere also points to the importance of interweaving theoretical and practical activities in technology education (Kilbrink 2013). Technical problem solving using digital models can be such an activity, both theoretical and practical, both learning in and about technology. In this article, teaching digital models should be understood as sometimes teaching in and sometimes teaching about digital models, and moreover, sometimes simultaneous teaching in and about digital models.

A model is a description or a representation of something, something real and concrete or something not yet realized, a mental idea (Gilbert et al. 2000). A model is not an exact replica of the original, but hold compromises and simplifications depending on the purpose and the use of the model. Technicians and engineers can use models to develop artefacts or processes, and the model can represent some special feature or function. Models in technology are for instance used for visual support when solving problems, to predict actions or events, to make decisions, and to communicate (Norström 2013; Elmer and Davies 2000; Seery 2017). This communication can be useful both when developing products and artifact but also in relation to already made objects. Only describing a product or a technical solution in words is often not enough; there is a need for sketches, drawings, or models to understand and mediate technology (Sjöberg 2013). Models are in that sense a language, and a way to conceive technological solutions (Davies and Elmer 2001). This language is specific for technology and constitutes part of the core of technological knowledge. In the context of technology education, models can be used in a similar manner and have a more descriptive approach.

A model can be a representation used in many different modalities; concrete, verbal, mathematical, visual, and gestural (Gilbert et al. 2000). Several of these modalities can also be represented digitally, through a digital tool, visualized on a digital screen, as a digital model. That is how digital models should be understood in this study, as represented through a digital tool, visualized on a digital screen. How then, is teaching digital models conducted, according to technology teachers? What are the aims and purposes, what content is chosen, and in what activities are the pupils supposed to engage? These questions, why teach something?, what should be taught? and how can teaching be planned and enacted?, are central for teaching irrespective of subject (Sjøberg 2010; Uljens 1997), and thereby relevant also for this study, which aims to describe teachers' experiences of teaching digital models.

Further, technology education is also characterized by an interest in technology. Ahlbom (2011) points to the importance in education of raising or enhancing pupils' interest in technological learning. So, to achieve successful learning, teachers need to start in and with the pupils' interest and at the same time develop that same interest. Ginestíe (2018) also points to the importance of developing pupils' interest in technology, in relation to an understanding of how digital tools can be used in society and how digital tools can be used to solve different problems. One often used digital tool, in society and in many technological professions, is computer aided design (CAD) where threedimensional objects (digital models) can be created. Technology teachers now use CAD in technology education, to meet the criteria of digital competence in syllabuses. Some schools in Sweden have access to a 3D-printer (Skolinspektionen 2019), which means that digital models can be printed to a physical model in plastics. A printed physical model can be helpful when it comes to supporting pupils' understanding of the iterative cycle of product development (Novak and Wisdom 2018), where different steps in the process are repeated; idea generation, sketches, building, testing et cetera. 
In addition to $\mathrm{CAD}$, digital models can also be created through algorithms, or sequences of actions (Åkerfeldt et al. 2018). Algorithms can be described with text or with words, or coded with texts or blocks into a program. When describing or coding, it is called programming. Programming can thereby contain both problem solving and coding ( (Skolverket 2011) with a focus on problem solving and electronical components and how they can be programmed, but also digital competence. Barak (2018) writes that technology education that uses micro control cards, such as Micro:bit or Arduino, is successful when it comes to developing pupils' ability to design, solve problems, and be creative. But Barak (2018) also adds that education can only be successful if the pupils have a basic understanding of the content; otherwise, there is a risk that the teaching becomes unreflected by the pupils, and the learning absent.

A brief presentation of the compulsory Swedish secondary school technology education will be presented next to provide a deeper understanding of the context in which this study was conducted.

\section{The Swedish context}

The study presented in this article has been conducted in Swedish lower secondary schools. In Sweden, lower secondary school, years 7-9 for pupils aged 13-15 years, is a part of the compulsory school. The compulsory school is governed by a national and common curriculum, with syllabuses for each subject. Technology education in Sweden has changed regularly during the last decades. In 1980, technology become a subject of its own for the first time. Before 1980, it was included as part of the science subjects (Lgr 80; Lpo 94; Skolverket 2011). Technology education is, as a result of the separation, a relatively young subject and lacks a distinct identity (Hagberg and Hultén 2005; Sjöberg 2013). In the current curriculum, Lgr11 (Skolverket 2011), changes in the technology syllabus were introduced in relation to pupils' documentation of their technical development. The core content for years 7-9, under the heading Working methods for developing technological solutions, includes the following phrase: "Documentation in the form of manual and digital sketches [...] with physical and digital models" (Skolverket 2011). Different schools have developed technology education differently, and as a result of that, teaching differs a great deal. Modes of teaching can even differ in the same school, depending of which teacher is teaching (Skolinspektionen 2014, 2019). Moreover, about half of the in-service technology teachers in lower secondary school have formal education for teaching the technology subject (Skolverket 2019). From the above, it is clearly important to investigate teachers' experiences of teaching digital models, to gain more knowledge and understanding in this area.

\section{Theory and method}

In this section, the theoretical and methodological principles used in this study are outlined, starting with a description of the phenomenology of the lifeworld, continuing with sample and data collection and finally, concluding with descriptions of the thematic analysis conducted. 


\section{Phenomenology of the lifeworld}

With the phenomenological lifeworld (Bengtsson 2013) as ontological and epistemological approach, a world experienced by a person is pluralistic. It is neither material nor mental, but consists of a complex intertwining of different subjects, objects, and experiences in a regional world, where the person acts. In this regional world which includes things, people, and activity, interactions occur, creating new experiences. All this constitutes the person's reality, and consequently different persons experience different realities (Bengtsson 2013), depending on their perspectives, positions, and previous experiences. Hence, in this study "experience" is a pertinent concept, understood as the analytical construct of the respondents' knowledge, beliefs, purposes, and intentions related to teaching digital models. The concept "phenomenon" should be understood as "that which appears" (Bengtsson 2013, p. 6), meaning that something must be understood by someone. Teaching digital models is the phenomenon in this study. It has a content and can be experienced, and the experiences can be described and interpreted. Empirical studies are, according to this approach, important in order to increase knowledge of the phenomenon studied (Bengtsson 2013; Kvale and Brinkmann 2014). However, investigating the teaching of digital models is limited to one particular reality, namely teachers' experiences, formulated in the research question.

Semi-structured interviews were chosen to correspond to the ontological assumption and the aim of this study, and to answer the research question. The method fostered a deeper understanding of teachers' lived experiences of teaching digital models and was considered to offer the best opportunity to make teachers' experiences visible. The empirical data were therefore collected through interviews, where the participants described the phenomenon from their point of view. Since teachers plan and design their lessons, they did during the interviews, in a reflected manner, describe teaching digital models based on their knowledge, beliefs, purposes, and intentions.

\section{Sample and data collection}

Technology teachers in Sweden are not a homogenous group, and it is known that teachers design their teaching based on local and personal preferences (Bjurulf 2008; Hartell 2015). Twelve technology teachers, five males and seven females, were strategically chosen for this study (Alexandersson 1994; Kvale and Brinkmann 2014). The strategy was to interview teachers who say that they teach digital models to ensure that they have experiences of the phenomenon investigated. Teachers with different backgrounds were chosen to cover the wide spectrum of teachers in service, concerning gender, teaching experience, and the size of the school. They all had formal teacher education, but not all in the technology subject. The interviewed teachers have been in service between 1 and 19 years and they teach different subjects in combination with technology. Table 1 is showing information about the participants. The aim of this study is not to distinguish between different teachers' teaching, but to collect different experiences and analyze them thematically.

The interviews were open in character, with a guide (see Appendix 1) for the questions (Kvale and Brinkmann 2014). The guide helped sustain focus on the phenomenon, that is teaching digital models, and it also supported the interviewees in their reflections and helped them grasp different aspects of the phenomenon. The guide included questions focused on the what-aspect and the how-aspect of the phenomenon, meaning that the interviewed teachers described not only what they teach and offered examples and explanations 
Table 1 Information about the interviewed technology teachers

\begin{tabular}{lllc}
\hline Teacher & Gender & $\begin{array}{l}\text { Formal education in } \\
\text { technology subject }\end{array}$ & $\begin{array}{c}\text { Teaching expe- } \\
\text { riences in year }\end{array}$ \\
\hline Teacher 1 & Female & No & 1 \\
Teacher 2 & Male & Yes & 3 \\
Teacher 3 & Female & No & 7 \\
Teacher 4 & Male & Yes & 19 \\
Teacher 5 & Female & Yes & 18 \\
Teacher 6 & Female & Yes & 10 \\
Teacher 7 & Male & Yes & 8 \\
Teacher 8 & Male & Yes & 11 \\
Teacher 9 & Male & No & 5 \\
Teacher 10 & Female & Yes & 5 \\
Teacher 11 & Female & Yes & 12 \\
Teacher 12 & Female & Yes & 15 \\
\hline
\end{tabular}

regarding what content they choose in this specific area, but also how they perform and enact that teaching and what activities they prepare for the pupils. These aspects gave the researchers deeper insights into the underlying structures of the interviewed teachers' experiences during the analysis phase (Alexandersson 1994). The interviews were designed to provide the teachers with opportunities to share their point of view, to answer the questions in their own way, and to clarify and exemplify in depth. The interviews were held at the teachers' schools, in a place decided by the teacher, in order to make the participant feel comfortable and relaxed. The interviews ran between 35 and $60 \mathrm{~min}$ and were recorded digitally. At some of the interview occasions, the researcher was given a view of the technology education classrooms. These conversations were not recorded, but gave the researcher a deeper understanding of the teachers' explanations. All twelve interviews were conducted by the first author, during October 2018 and September 2019, and yielded rich data which allowed for themes to be established. After nine interviews, no new themes were established, and the three latter interviews gave no further information. Therefore, the data collection ended at twelve interviews.

\section{Data analysis}

The interviews were transcribed in full by the first author. Transcription constitutes a transformation from spoken language to written, and require interpretation by the person transcribing (Kvale 1996). Therefore, the aim of this study guided the transcriptions to focus on what the interviewees said, on the content in their explanations. Another focus in the transcriptions has been readability.

When investigating an under-researched area (as in this study) a rich description of the data set is useful (Braun and Clarke 2006), and an inductive method without pre-existing coding frames for reporting patterns or themes is also helpful (Braun and Clarke 2006). Therefore, a thematic analysis was used in this study, to report the life world experiences, meanings, and realities of the participants. The analysis was performed in two steps. In the first step, themes were extracted from the data set. In the second step, the synthesis, an indepth analysis extracted teaching aspects within the themes. 
In the first step of the analysis, the researchers listened to the audio files and read the transcriptions several times in parallel with the interviews. The material was studied iteratively in order for the researchers to familiarize themselves with the data. Initially, a short descriptive note was added to segments or elements from the data set associated with the phenomenon studied (teaching digital models). The notes then were organized into meaningful groups and coded. Examples of these initial codes are design, abstract, basic, interest, software, programming, and print. This coding was open, meaning that the researchers analyzing the material had no pre-determined codes. This coding process continued systematically with all twelve transcriptions, however the three latter transcriptions did not generate any new codes. The codes were organized continuously with respect to similarities and common features, and then reduced and organized into themes. The themes were finally reviewed, defined, and named in an iterative process including all three authors and constitute the results from the first analyzing step. Since the themes represent teachers' experiences of their own aims and purposes related to the teaching of digital models, further analysis was needed to answer the research question and reach in-depth understanding.

In the second step of the analysis, the synthesis, the first author once again read the twelve transcriptions. This second reading focused on teaching content and methods of teaching within each theme. Excerpts, words, and sentences from the interviewed teachers, associated with a specific theme, were labeled. Some examples of teaching content and methods of teaching found and labeled during the reading are product development, digital simulations, films, and 3D-printer. These labels were coded as teaching aspects and each theme was assigned a number of important teaching aspects. However, the transcripts show that the teaching aspects from different themes sometimes were simultaneous described, which resulted in an overlapping of themes. Sometimes two of the themes overlapped, sometimes three.

The empirical data form four themes of experiences that reflect the interviewed teachers' aims and purposes in teaching digital models. The themes also contain different teaching aspects, that is teaching content and methods of teaching, related to the teachers' aims and purposes. The resulting synthesis describes how the four themes relate to each other and outlines where aspects from different themes are used for various purposes. The results will be presented next.

\section{Results}

The aim of this article is to describe different experiences of teaching digital models in lower secondary technology education. The results are organized to present the four themes, including the interviewed teachers' aims and purposes in teaching digital models, first. Thereafter the synthesis is presented, describing teaching aspects and relations between the themes. Technology teachers experience the teaching of digital models as the following themes:

(a) Enhancing and integrating other subjects,

(b) Visualizing technology to the pupils,

(c) Enabling digital modelling,

(d) Preparing pupils for the future. 
Each theme is presented with excerpts selected to show examples of how teachers describe their teaching and to show a variety from the sample. The excerpts are referred to a specific teacher, (Teacher 1) to (Teacher 12), but should be understood as a representation of the presented experience, or the teaching aspects within the theme. However, the same teacher can have experiences referring to different themes, as an individual teacher can teach with different aims and purposes. In every excerpt, focus is on the teaching of digital models, unless otherwise stated.

\section{Enhancing and integrating other subjects}

The empirical data of this study show that teaching digital models in lower secondary technology education is used to enhance and integrate other subjects in school. Digital models seem to be useful for integrating other subjects and are appreciated when it comes to creating common projects. Above all, some of the interviewed teachers discuss mathematics and crafts as important subjects to enhance and integrate in relation to technology education. Mathematical concepts are given a major focus in teaching and pupils can work with concepts such as angles, measurements, and coordinate systems. Pupils also work with their spatial ability, with geometrical objects, and with different dimensions. Teacher 7 gives voice to this focus:

I will work with $\mathrm{X}, \mathrm{Y}$ and $\mathrm{Z}$-axis. I will work with the concept volume, so I can connect it to mathematics, to lessons in mathematics. So they [pupils] see where they can use it in other subjects. [...] Yes, but it is interesting that, math, I think I do it very much in technology. Trying to make them [pupils] understand why they need to learn mathematics. (Teacher 7)

Craft is integrated with technology partly to create physical models of the digital models, designed by the pupils in digital environments. In the technology subject, pupils design for instance a piece of jewelry digitally in a CAD-program and can thereafter print it in a 3D-printer. In crafts, the printed jewelry model is used for molding.

You know, if you take it and put it into sand, and then mold so... A form, so they [pupils] can do the same jewelry in tin. (Teacher 1)

Another common project, described during the interviews, is programming using a micro control card. Teacher 5 described that the aim of teaching digital models in technology is to generate data for mathematical calculations.

$\ldots$ and they can program it [Micro:bit] to measure temperature. To measure both out- and inside temperature. After that, pupils will do calculations in math. So, we thereby connect technology and math. (Teacher 5)

More similar projects and activities have been mentioned during the interviews, where digital models in technology generate data for mathematical calculations and/ or diagrams. One result from this study is therefore that teachers are teaching digital models as a means to enhance and integrate other subjects. Yet another result is that teaching digital models can visualize technology to the pupils, and this theme will be described in the following section. 


\section{Visualize technology to the pupils}

Some teachers in this study experience that it is abstract to teach technical systems. To make technical systems more tangible and concrete, teachers expressed that they use digital models. According to some of the interviewed teachers, digital models provide an opportunity to visualize what otherwise would be difficult to show, and digital models also make difficult technical systems or technical solutions more graspable. In the theme Visualize technology to the pupils, some interviewed teachers use ready-made digital models to show pupils technology that already exists. By ready-made digital models, interviewed teachers mean movies, Youtube clips, or simulations, used to represent some part of the real world. The purpose of using these ready-made digital models is to bring about discussions in class of how technology is being used or what the purpose of a certain technology is. The aim of the lessons is also to identify advantages and disadvantages in technology and discuss them as an activity in class. One interviewed teacher says:

I have some movies [...]. So, from there we can discuss. Copying. [...] to start a discussion, to start a conversation with them [the pupils] about the benefits, dangers, we can copy almost everything soon. (Teacher 8)

Films provide a good introduction to dialogues and conversations in class, according to some interviewed teachers with experiences in this theme, since questions can be asked based on what has been seen. Simulations are also mentioned as useful in teaching for dialogues and conversations.

It becomes illustrative, of how it works. I mean, if you teach technical systems and talk about the internet and things like that, to make it more distinct. It is so abstract. [...] Well, then it is a clear model, of how it is in reality. How it is, seen from behind. (Teacher 3)

Simulations give pupils a fast response and quick feedback on learning the specific teaching content, some interviewed teachers say. For instance, pupils can observe if the bridge under construction is going to break or hold, or if the lamp in the electric circuit is going to light up or not.

In conclusion, the aim of teaching digital models according to this theme is to make complicated technical systems more graspable and concrete, with support of digital pictures, movies, and simulations. The support enhances discussions in class, and readymade digital models or programs are often used for that. In the next part, the third theme will be described, that is teaching where pupils themselves create digital models: digital modelling.

\section{Enabling digital modelling}

From the empirical data collected in this study, it is clear that technology teachers can teach digital models to give pupils opportunities to learn the process of modelling. In other words, this theme is about enabling digital modelling. Teaching activities include designing in CAD or programming. Modelling and programming are iterative, even when the process is digital, and teachers say they want pupils to realize that the process is not linear. Pupils test, try, retry, and redo during this teaching, some interviewed teachers say. Teacher 
7 gives an example of programming as a digital model in the following excerpt, when talking about a task where pupils are programming a game:

... when we program the games, you can say that you create a digital model of the reality, so to speak. If you are a figure catching apples falling down, you make a digital image of your idea. That is a model, a digital image of it. (Teacher 7)

When describing the teaching of digital modelling, some interviewed teachers say they initially start teaching the specific software used. To be able to model digitally, using digital tools, pupils need to handle the software. When teaching programming, teachers give examples of how they use a simple interface, like block-programming instead of text-based programming. The reason for using block-programming is that pupils otherwise risk getting caught in syntaxes, even though teachers say they want to move on to text-programming. Electronic components or robots are also sometimes used when teaching digital modelling, for exemplifying and concretizing programming, and for pupils to work with physical objects. Some teachers said in interviews that when programming, simulations on a screen alone are not enough for learning. Concrete and physical material as different components are experienced by teachers as necessary to complement teaching, and many teachers have bought electronic components for that occasion.

Teachers describe that digital models, made by pupils in CAD, are simple with basic geometrical forms, like jewelry or name-tags. From these basic objects, pupils are free to choose and design new objects to model, often based on their interest. What is designed is not important, since the learning content is to handle the software, some interviewed teachers say. Pupils often need to learn more advanced functions in the software on their own. The following excerpt shows that the focus among some interviewed teachers is that the software, not the designed object, is the learning content:

In one of the basic tasks I teach, pupils will design a key tab, with free design, to test

the program. [...] The task is to understand the program. (Teacher 2)

Sometimes, according to the interviewed teachers, pupils can create a physical model from their digital original. They print the objects in a 3D-printer. The 3D-printer is also used to exemplify contemporary and quick ways to create physical objects.

Well, they see a modern technique. That you can, like do a model. So. It is for showing how it works. (Techer 12)

The theme of enabling digital modelling is experienced as associated with different teaching aspects. Interviewed teachers say that they need to start teaching the software for pupils to be able to design digitally, program digitally, or print a physical object. The iterative process of modelling is experienced by the pupils while modelling. The fourth and last theme identified in this study concerns teachers' experiences of preparing pupils for the future.

\section{Preparing pupils for the future}

Some participating teachers in this study described during the interviews that they find it important to prepare pupils for the future, for higher education, for professions, and also for day-to-day life. Teachers say they want to present different alternatives for higher education and different possible engineering professions using digital models. They also want to inspire pupils to pursue a technological interest, according to 
the interviews. Another important aspect of teaching, according to some interviewed teachers, is that pupils need to be informed of the fact that more and more products and artefacts today are manufactured through digital drawings and digital models. Pupils also need to be informed of how to relate to programmed systems, since a great many things today consist of programmed items. These are important knowledge for being able to act as an adult, for any citizen, teachers say.

Teaching digital models is described mainly in two ways; either with practical tasks using digital tools, where pupils themselves create models or programs; or with a more theoretical approach using films, pictures, or simulations, where discussions become the dominant part. In the interviews, teachers share experiences showing that concerning both the practical and the theoretical teaching, discussions are general. The aim of the teaching is to stimulate interest and inform pupils about different digital tools, to let pupils use digital tools and software, and to inspire them to consider pursuing technical careers. The following excerpt has been chosen to illustrate how one interviewed teacher describes the teaching of digital models for preparing pupils for the future.

I would like as many [pupils] as possible to attend technological education in upper secondary school. [...] But much of the teaching is to show them what exists, getting them interested. (Teacher 3 )

Using digital models is a good choice for inspiring and stimulating interest, teachers say, because many pupils think it is fun and novel. Showing new technologies can give pupils better options for their choice of upper secondary school programme. In order to encourage pupils to consider pursuing technological careers, teachers tell pupils about staffing needs, and what knowledge are required to be employed.

Corporations need people who can draw digitally. And, they print everything in $3 \mathrm{D}$, first, before they mold these hydraulic presses. Modelling and printing. (Teacher 8)

Furthermore, teachers point out during the interviews that it is important to learn digital models from a more general perspective, not only to pursue higher education. Teachers teach digital models so that pupils can interpret different kinds of models, commonly used in society. General knowledge of how digital models are being used in different professions is described when teachers in the interviews talk about teaching everyday use of technology. The examples given are common, but noteworthy, teachers express that general knowledge is important even for those pupils not choosing a future technological career, since all people need to feel comfortable around technology and understand a little about structures underlying programmed systems.

They [pupils] need to know this. First of all, know little, knowledge about technology, and about what is going on around the world. To understand what is happening. (Teacher 2)

So, technology teachers are teaching digital models and use ready-made models in teaching, as a method for inspiring pupils, to create an interest in further technology education, to encourage pupils to consider technological professions, and for more general knowledge about technology. In this theme, teaching is both practical and theoretical, but the aim is to provide information about, show, and present modern technology, as well as to generate an interest in technology. 
Table 2 Four themes of technology teachers' experiences of teaching digital models, and corresponding teaching aspects

Themes - aim of teaching digital model

Enhancing and integrating other subjects

Visualizing technology to the pupils

Enabling digital modelling

Preparing pupils for the future
Teaching aspects- teaching content and/or methods

Mathematical concepts

Generating data for mathematical analysis

Preparations for crafts

Concretize technology

Basis for discussions

Iterative process

Handling software

Physical objects

Technological education programmes

Technological professions

General technological knowledge

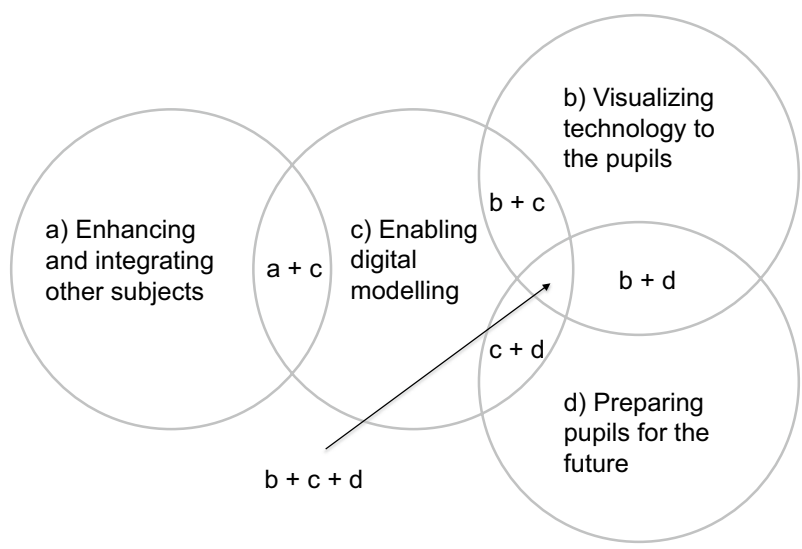

Fig. 1 Combinations and relations of technology teachers' experiences of teaching digital models

\section{Synthesis}

Learning is always about something, and teaching is about making learning possible through using different methods. In this text, teaching content and methods are called teaching aspects, and the aim and purpose of teaching a specific area are associated with some specific teaching aspects. Therefore, teaching digital models also involves different teaching aspects which reflect teachers' aims and purposes in their teaching.

In this study, the aims and purposes of teaching digital models are described in four themes, partly overlapping each other. The overlaps is the result of different teaching aspects associated with more than one theme. Technology teachers can teach digital models with one or more of the themes in focus simultaneously. Before describing the combinations and relations between the themes, the teaching aspects of teaching digital models need to be presented and related to the four themes. The teaching aspects have already been introduced and mentioned in the statements of the themes above, but are also summarized in Table 2 below. The four themes are presented to the left, 
and teaching aspects are presented to the right. In the following text, the connections between the themes of Fig. 1 will be described based on the connected teaching aspects of Table 2 .

The four themes are related and they have common teaching aspects. This is illustrated in Fig. 1 where the themes are represented by the circles and the overlapping areas are representations of teaching aspects, that is teaching content and methods, that are used for fulfilling multiple aims and purposes.

Teachers experience that teaching digital models is a good way of enhancing and integrating other subjects, and they use software like CAD and block-programming for that purpose. They also sometimes use hardware like micro-control cards when teaching. Pupils are thereby working with digital models when they provide mathematics with data, when they work with mathematical concepts, or when they make substrates for manufacturing in crafts. Using digital models for integrating technology with other subjects requires pupils to be engaged in activities with the digital models. They are modelling digitally, even though modelling is not the aim of the teaching. When teaching for integrating other subjects, the 3D-printer can also be used, according to interviewed teachers, so that pupils can print physical models and use them for molding. Enabling digital modelling then provides enhancing and interacting other subjects, shown in Fig. 1 as $(\mathrm{a}+\mathrm{c})$. Examples of common aspects are handling software, physical objects, mathematical concepts, generating data for mathematical analysis, and preparations for crafts, see Table 2. Teacher 11 explains a situation where mathematical concepts and preparations for craft are the teaching content and handling the software is the method.

But you take very simple objects, that they [pupils] have designed on their own. [...]

They started with a name tag. A name tag they later could do in crafts. That is why it

[the name tag] has to have right dimensions. (Teacher 11)

Teaching that aims for enabling digital modelling and visualizing technology to the pupils is multifaceted Fig. $1(\mathrm{~b}+\mathrm{c})$. Interviewed teachers say that it is important for pupils to understand that modelling is an iterative process which moves back and forth between generating ideas, producing sketches, modelling, and testing. Pupils are encouraged to test and redo on their own when results are not as expected. Teachers use different software and programs in the activities, like CAD or block-programming. Teaching then concerns handling the software and the iterative process at the same time. Some teachers also express that teaching that enables digital modelling includes making a physical object from the digital object. The focus of the described activities is to show modern and novel methods for technological manufacturing, and to concretize technology. Examples of common aspects are concretizing technology, iterative process, handling software, and physical objects, see Table 2.

One means of using 3D-printed physical objects when teaching to enabling digital modelling, can also be to prepare pupils for the future, Fig. $1(\mathrm{c}+\mathrm{d})$. Teachers describe in the interviews that one intention with technology education is to raise an interest among pupils for technology and for technological educations and professions. They attempt to stimulate interest by telling the pupils about different professions that use printed models before production, and pupils are allowed to try these methods, hopefully to develop an interest. Enabling digital modelling is also used in activities when teachers teach programming, where the aim is to prepare pupils for the future, for the programmed contemporary society. Teachers teach to make pupils understand that programmed machines or systems are man-made with different purposes, and that the machines or systems are just as good as they are made. Examples of common aspects are handling software, physical objects, 
and technological educations and professions, see Table 2. Teacher 10 describes a situation where pupils are programming. The teaching content is handling the software, and at the same time, handling the software is a method for discussions about programming, another teaching content:

It is about them being confident as adults. [...] You cannot just trust these programs.

They get as good as they are made. (Teacher 10)

Teachers, teaching for visualizing technology, often use ready-made digital models as a basis for discussions, such as films, animations, or different applications. In those activities, when teachers are discussing together with the pupils, abstract technology becomes graspable. Pupils can see and be aware of technology used in everyday surroundings. These discussions prepare pupils for the future, according to the interviewed teachers, by making pupils conscious of the technology that surrounds them, shown in Fig. $1(b+d)$. Above all, teachers point out that teaching abstract concepts and abstract systems can be scaffolded with digital models. Knowledge of abstract concepts and systems is important for all pupils, even for those pupils not interested in higher education in technology. Examples of common aspects are basis for discussions, concretizing technology, and general technological knowledge, see Table 2.

Teachers participating in this study can also teach digital models with teaching aspects from three of the themes simultaneously, to fulfill different aims and purposes, illustrated in Fig. $1(\mathrm{~b}+\mathrm{c}+\mathrm{d})$. Enabling digital modelling can be taught together with preparing pupils for the future and visualizing technology to the pupils. One example of this is when teachers teach programming with for instance Micro:bit; pupils are engage in activities with digital modelling, and at the same time, electronical components make programming more concrete, as discussions about programmed applications and systems. This example contains the same teaching aspects from three different themes of aims and purposes.

The synthesis shows that teaching digital models is not centered on only one objective, and teaching content and methods may differ, but also overlap between the various aims and purposes. Hence, Fig. 1 indicates that the teachers did not experience the teaching of digital models as one single idea but as an amalgam of multiple ideas that can mean different things in different situations or contexts. Digital models, as a concept and a practice, have many meanings for the teachers of this study.

\section{Discussion}

The point of departure for this article is to present technology teachers' experiences of teaching digital models. By comparing previous findings and knowledge of models in technology education, digital design using $\mathrm{CAD}$, programming and the character of technology subject, with the empirical data from this study, discussions about the resulting themes can ensue and be understood. One strength of research with a lifeworld approach is the possibility to discuss the themes in relation to other studies and theories (Bengtsson 2013). Mishra and Koheler (2006) explain that introducing new technologies to a content will influence the teaching of that content. Teaching models is for some teachers now teaching digital models, and technology teachers' experiences of this new teaching are important to clarify.

The results of this study, the four themes and the teaching aspects, answer the pedagogical questions of why?, what? and how? in relation to the teaching of digital models. 
The interviewed technology teachers have answered questions about what and how, but the main focus in their responses has been why they teach as they do, and why they choose content as they do. It seems more important for the interviewed teachers to justify their teaching than just to explain it. This insight can be related to the role of the technology subject in Swedish schools. Technology education has a vague identity and, as stated above, there is no central core of content (Hagberg and Hultén 2005; Sjöberg 2013). Teachers seem to try to strengthen the role of the subject by justifying their pedagogical choices and arguing why their teaching is important.

Another finding of this study is that digital models are a means for enhancing and integrating other subjects, such as mathematics and crafts. Integrating other subjects gives pupils a holistic grasp of the teaching content, but what are the consequences of letting the technology subject being used as backup for other subjects? What will happen with the core content and with the identity of the technology subject, considering the fact that these aspects are already unclear (Hagberg and Hultén 2005; Sjöberg 2013)? Teachers are struggling to promote the technology subject on its own merits on the one hand, and on the other hand, they are using it as a means for other purposes in other subjects. Previous research has highlighted the risk that the technology subject when integrated with mathematics and science may serve to enhance the goals for those other subjects and that integration may also detract from the integrity of technology as a subject (Williams 2011). During the interviews, the examples described by the teachers often point to the learning objectives of other subjects.

Using digital models as a way of showing technological solutions to others and to oneself, as a language of technology (Davies and Elmer 2001), is not an explicit goal/ aim in teaching digital models, according to the results of this study. Thereby, one characteristic of technology may be missing, if pupils are not made aware of the role and function of models; to communicate, to support ideas, to transform mental ideas to concrete models, and to make the ideas available to others. As stated above, Swedish technology education differs a great deal between different schools (Skolinspektionen 2014, 2019). Based on the findings of the present study, it can now also be stated that education concerning the teaching of digital models also differs. There are different experiences of teaching digital models, which can be interpreted as an indication that there is no consensus regarding teaching content or methods of teaching digital models, the progression of the teaching content, or the levels of knowledge that pupils are supposed to acquire. Teachers did not share a common knowledge base during the interviews. The aim and purpose of teaching digital models, the four themes, seem more important than the specific content.

Previous research has pointed to the importance of interweaving theoretical and practical activities in technology education (Kilbrink 2013). And that is what happens when teachers for instance enabling digital modelling and prepare pupils for the future. Pupils engage in a practical activity when modelling using digital tools, and get insights into the programmed contemporary world or different professions. The results show that pupils are given opportunities to learn in and about technology. Furthermore, teachers include a normative component (de Vries 2005), when digital models representing different kinds of technology are discussed in terms of consequences and values in technology education. In this discussion, it is important to highlight that teachers express that they need pedagogical support to visualize technological content that pupils find abstract. Teachers want to concretize this difficult teaching content, and digital models are considered appropriate for that aim. Digital models often open up for discussions about advantages and disadvantages of the specific technology of interest to 
the pupils and the teaching content can be varied a great deal, for instance to ask how search terms are bouncing on the internet, and what strengths are involved in lattice constructions.

To continue, technology teachers find it important sometimes to concretize the digital models, made by pupils when modelling digitally. They print the designed objects in a 3D-printer to show modern manufacturing methods, or they use electronic components to show connections between programming and controlling. In this way, pupils are given opportunities to work with the iterative cycle of product development (Novak and Wisdom 2018), as they can try out, redo, and change their objects or programmed codes. This is also an example of teachers interweaving theory and practical activities (Kilbrink 2013), and an example of combining the teaching of technological knowledge with technological activities (Mitcham 1994), producing and using technology. Since the technology subject has a dual nature with both practical and theoretical activities (Gibson 2009), is it surprising that the dual nature is not mentioned when the interviewed teachers describe their teaching. Could it be that technology teachers usually do not discuss the subject with colleagues? Norström (2014) suggests that without a professional common base of what technological knowledge can be, and without a professional common base of terminology, "discussions and transfer of information become unnecessarily difficult" (Norström 2014, p. 33). The results of this study corroborate the lack of a common conceptual basis concerning digital models.

The overall result from this study is that there is not one way to experience digital models, and therefore not one way to teach digital models. Digital models are sometimes used as a learning objective (for instance learning the software), and sometimes used as a means for other learning objectives (for instance providing inspiration for further technological studies). Moreover, some teachers do not have organized conferences or shared arenas to discuss the technology subject with others (Skolinspektionen 2019). Some technology teachers have to make individual decisions about their teaching. It seems possible that these results explain why it becomes difficult to discuss teaching digital models, when the teachers mean different things in different situations, but use the same word, and further, when the concept digital models is used in the technology subject syllabus without a clear definition (Skolverket 2011). This can explain and be one reason why technology teachers have trouble interpreting the syllabus (Bjurulf 2008; Hartell 2015), that the concept digital models is vague and not well defined. To improve the technology subject, and improve the teaching of technology, discussions of teaching digital models should be more nuanced and specific. Teaching design using digital design tools is one example of an area that is more nuanced, digital visualization of electronical circuits is another. Using digital tools to examine and test sustainable constructions is also another area to discuss separately. These are just examples of teaching digital models, which cannot be discussed as one type of teaching. If discussions become more nuanced and more specific, our knowledge of pupils' optimal learning or teachers' best practice can increase.

However, Skolinspektionen (2014) pointed out in their report that a great many areas in technology education are unreflected, but from the results of this study, it can be stated that technology teachers are reflecting. They are reflecting upon why they teach digital models, as the four themes indicate, but there is a lack of reflection concerning the choice of content and method. 


\section{Conclusions}

The results presented in this article show that technology teachers teach digital models with different aims and purposes, that the teaching content differs, and that pupils are given different prerequisites for learning digital models. The thematic analysis of the interviews resulted in four descriptive themes of the interviewed teachers' experiences of teaching digital models; Enhancing and integrating other subjects, Visualizing technology to the pupils, Enabling digital modelling and finally, Preparing pupils for the future. Each theme also has teaching aspects, such as the teaching content and methods used. Hence, there is not one way to experience the teaching of digital models, and a conclusion from this study is that discussions about this area need to be more nuanced and specific to provide a common knowledge base in this area. Since technology is rapidly changing and developing, the meaning of concepts such as digital models can also change over time. It is therefore necessary to understand how digital models are experienced, understood and interpreted in education today, to be able to understand any future developments. More specific discussions can also help highlight the technological outcomes in integration with other subjects. Further, more nuanced discussions can better include what requirements are reasonable for pupils in lower secondary school, regarding some specific part of digital models, for instance CAD, or programming, and could also include digitalization at a more general level. If actors in technology education start to discuss these issues in a more nuanced and specific manner, more knowledge of pupils' learning, individualization, the level of teaching, planning and designing lessons, and different applications or programs can help enhance and develop the technology subject. Further, if teachers are talking about the same thing when discussing these questions, it can help transfer the teachers' own knowledge about digital models into teaching, and it can help pupils to acquire a conceptual basis.

Technology education is researched both nationally and internationally, and many areas are well defined, but not the process when pupils in lower secondary school create and design in digital environments. When interviewing technology teachers for this study, many of them talked about CAD as an important area of education. It gave us insights into the need for more knowledge about teachers' experiences of teaching involving CAD. Therefore, to get a more holistic view of technology education, aspects of creating and designing in digital environments need to be elaborated on in future studies. Another topic for further research can be to investigate how the use of digital models affect pupils' learning or interest in technology.

\section{Appendix 1}

See Table 3. 
Table 3 Interview guide

Question
Can you describe an example or assignment where
pupils work with models or modelling using digital
tools?

Supplementary questions

How did you choose your assignment?

Do you have more examples?

Have you taught something else previously?

How do you explain digital models and digital modelling to the pupils?

What convinced you to choose that?

Do you need to do any preparations for that assignment?

How do you work with progression in that area?

How do you find out what the pupils already know? What does it mean to you, to teach this?

What do you want the pupils to learn (from the chosen assignment)?

How do you explain the assignment to the pupils?

What are the technological areas in your assignment, when you are teaching digital models or digital modelling?

What programs or applications do you use?

What competences do you find important for you to have when teaching digital models or digital modelling?

How do you organize assignments with digital models and digital modelling in the classroom?
How does this learning become visible?

What else can pupils learn from this assignment?

What words and concepts do you use?

Are there specific words or concepts you think belong to the assignment?

What usually causes difficulties for the pupils?

How do you help them? Are there other ways to explain?

What else do pupils find difficult?

How can the digital tool contribute to an understanding of that technological area?

Why did you choose that?

Were there more reasons?

Anything else?

What motives are there for that way to work?

What is your role in the classroom, when pupils are working with the assignment?

Can you give more examples?

Can you clarify?

Can you tell me more?

What do you mean with ...?

Can you describe that?

Can you develop that?

When you say... what ... how...?

How do you concretize that?

Author contributions All authors contributed to the study conception and design. The first draft of the manuscript was written by Author 1 and all authors commented on previous versions of the manuscript. All authors read and approved the final manuscript.

Funding Open access funding provided by Karlstad University.. This work was supported by Region Värmland and Karlskoga Kommun.

Open Access This article is licensed under a Creative Commons Attribution 4.0 International License, which permits use, sharing, adaptation, distribution and reproduction in any medium or format, as long as you give appropriate credit to the original author(s) and the source, provide a link to the Creative Commons licence, and indicate if changes were made. The images or other third party material in this article are included in the article's Creative Commons licence, unless indicated otherwise in a credit line to the material. If material is not included in the article's Creative Commons licence and your intended use is not 
permitted by statutory regulation or exceeds the permitted use, you will need to obtain permission directly from the copyright holder. To view a copy of this licence, visit http://creativecommons.org/licenses/by/4.0/.

\section{References}

Ahlbom, H. (2011). Teknikintresserad? Jag?. In Hansson, Nordlander, Skogh (Red.), Teknikutbildning för framtiden - perspektiv på teknikundervisningen i grundskola och gymnasium. Stockholm: Liber.

Åkerfeldt, A., Kjällander, S., \& Selander, S. (2018). Programmering-introduktion till digital kompetens $i$ grundskolan. Liber AB.

Alexandersson, M. (1994). Den fenomenografiska forskningsansatsens fokus. In Starrin, B., \& Svensson, P. G. (1994). Kvalitativ metod och vetenskapsteori. Lund: Studentlitteratur.

Bengtsson, J. (2013). With the lifeworld as ground. A research approach for empirical research in education: The Gothenburg tradition. Indo-Pacific Journal of Phenomenology, 13(1), 01-18.

Bjurulf, V. (2008). Teknikämnets gestaltningar : En studie av lärares arbete med skolämnet teknik (PhD dissertation). Karlstads universitet, Karlstad. Retrieved from http://urn.kb.se/resolve?urn=urn:nbn:se: kau:diva-2729.

Bjurulf, V. (2011). Teknikdidaktik. Norstedt.

Braun, V., \& Clarke, V. (2006). Using thematic analysis in psychology. Qualitative Research in Psychology, 3(2), 77-101.

Davies, T., \& Elmer, E. (2001). Learning in design and technology: The impact of social and cultural influences on modelling. International Journal of Technology and Design Education, 11(2), 163-180.

De Vries, M. J. (2005). The nature of technological knowledge: Philosophical reflections and educational consequences. International Journal of Technology and Design Education, 15(2), 149-154.

Department of education and skills. (2017). Irish Education System. Retrieved from https://www.education. ie/en/.

Elmer, E., \& Davies, T. (2000). Modelling and creativity in design and technology education. In J. K. Gilbert \& C. J. Boulter (Eds.), Developing models in science education (pp. 137-156). Dordrecht: Springer, Netherlands.

Gibson, K. (2009). Technology and design, at key stage 3, within the Northern Ireland curriculum: Teachers' perceptions. International Journal of Technology and Design Education, 19(1), 37-54.

Gilbert, J. K., Boulter, C. J., \& Elmer, R. (2000). Positioning models in science education and in design and technology education. In J. K. Gilbert \& C. J. Boulter (Eds.), Developing models in science education (pp. 3-17). Dordrecht: Springer, Netherlands.

Ginestié, J. (2018). Using computer technologies in design and technology education: Teaching-Learning process. In M. J. de Vries (Ed.), Handbook of technology education (pp. 403-418). Cham: Springer International Publishing.

Hagberg, J. E., \& Hultén, M. (2005). Skolans undervisning och elevers lärande i teknik: Svensk forskning $i$ internationell kontext. Vetenskapsrådets rapportserie. Vetenskapsrådet.

Hartell, E. (2015). Assidere Necesse Est: Necessities and complexities regarding teachers' assessment practices in technology education ( $\mathrm{PhD}$ dissertation). Stockholm. Retrieved from http://urn.kb.se/resol ve?urn=urn:nbn:se:kth:diva-160092.

Kilbrink, N. (2013). Lära för framtiden: Transfer i teknisk yrkesutbildning (PhD dissertation). Karlstad. Retrieved from http://urn.kb.se/resolve?urn=urn:nbn:se:kau:diva-16378.

Koehler, M. J., \& Mishra, P. (2005). Teachers learning technology by design. Journal of Computing in Teacher Education, 21(3), 94-102. https://doi.org/10.1080/10402454.2005.10784518

Kvale, S. (1996). Interviews: An introduction to qualitative research interviewing (p. 1996). Sage.

Kvale, S., \& Brinkmann, S. (2014). Den kvalitativa forskningsintervjun. Studentlitteratur.

Lgr 80, Läroplan för grundskolan, (1980). Allmän del: mål och riktlinjer, timplaner, kursplaner. Stockholm: Skolöverstyrelsen/Liber Utbildningsförlaget.

Lpo 94, Läroplan för det obligatoriska skolväsendet, (1994). Stockholm: Utbildningsdepartementet, www. skolverket.se

Marton, F. (2015). Necessary conditions of learning. Routhledge.

Marton, F., \& Tsui, A. (2004). Classroom discourse and the space of learning. Erlbaum.

Minestry of New Zealand. (2017). Technology in the New Zealand Curriculum 2017. Retrieved from http:// nzcurriculum.tki.org.nz/The-New-Zealand-Curriculum/Technology.

Mishra, P., \& Koehler, M. J. (2006). Technological pedagogical content knowledge: A framework for teacher knowledge. Teachers College Record, 108(6), 1017-1054.

Mitcham, C. (1994). Thinking through technology. The University of Chicago Press. 
Nia, M. G., \& de Vries, M. J. (2016). Models as artefacts of a dual nature: A philosophical contribution to teaching about models designed and used in engineering practice. International Journal of Technology and Design Education, 27(4), 627-653. https://doi.org/10.1007/s10798-016-9364-1

Norström, P. (2013). Engineers' non-scientific models in technology education. International Journal of Technology and Design Education, 23(2), 377-390. https://doi.org/10.1007/s10798-011-9184-2

Norström, P. (2014). How technology teachers understand technological knowledge. International Journal of Technology and Design Education, 24(1), 19-38.

Novak, E., \& Wisdom, S. (2018). Effects of 3D printing project-based learning on preservice elementary teachers' science attitudes, science content knowledge, and anxiety about teaching science. Journal of Science Education and Technology, 27(5), 412-432.

Seery, N. (2017). Modelling as a form of critique. In P. J. Williams \& K. Stables (Eds.), Critique in design and technology education (pp. 255-273). Springer.

Sjøberg, S. (2010). Naturvetenskap som allmänbildning: En kritisk ämnesdidaktik. Studentlitteratur.

Sjöberg, S. (2013). Grundläggande tekniska förmågor. In: Hallström, Klasander (eds.), Ginners teknikdidaktiska handbok. Några teser om teknik, skola och samhälle. Norrköping: Linköping University.

Skolinspektionen. (2014). Teknik - gör det osynliga synligt. Om kvaliteten i grundskolans teknikundervisning. Stockholm. Retrieved from http://www.skolinspektionen.se/Documents/Kvalitetsgranskning/tekni k/kvalgr-teknik-slutrapport.pdf.

Skolinspektionen. (2019). Digitala verktyg i undervisningen. Matematik och teknik $i$ årskurs 7-9. Stockholm. Retrieved from https://www.skolinspektionen.se/globalassets/publikationssok/granskningsrapp orter/kvalitetsgranskningar/2019/digitala-verktyg/rapport-digitala-verktyg-i-undervisningen.pdf.

Skolverket. (2019). Grundskolan - Personalstatistik med behörighet - per ämne och kategori. Retrieved from http://siris.skolverket.se/reports/rwservlet?cmdkey=common\&notgeo=\&p_verksamhet sar=2016\&p_omgang $=1 \&$ report=personal_amne2\&p_skolkod=\&p_lankod=\&p_kommunkod=\&p_ hman=00\&p_niva=H\&p_amne $=18 \&$ p_verksform $=11$.

Skolverket. (2011). Läroplan för grundskolan, förskoleklassen och fritidshemmet 2011. (Revised 2017) Retrieved from https://www.skolverket.se/publikationer?id=3813.

Svensson, M. (2011). Att urskilja tekniska system: Didaktiska dimensioner i grundskolan (Studies in science and technology education, nr. 2011:33). Doktorsavhandling, Linköping: Linköpings universitet.

Uljens, M. (1997). Didaktik: Teori, reflektion och praktik. Studentlitteratur.

Williams, J. (2011). STEM Education: Proceed with caution. Design and Technology Education: An International Journal, 16(1), 26-35.

Barak, M. (2018). Teaching electronics: From building circuits to system thinking and programming. In M. J. de Vries (Ed.), Handbook of Technology Education (pp. 337-360). Cham: Springer International Publishing.

Publisher's Note Springer Nature remains neutral with regard to jurisdictional claims in published maps and institutional affiliations. 